\title{
An Investigation of the Effectiveness of Concept Mapping on Turkish Students' Academic Success
}

\author{
Yavuz Erdoğan \\ Correspondence: Yavuz Erdoğan, Atatürk Education Faculty, Marmara University, Turkey
}

Received: February 14, 2016 Accepted: February 25, $2016 \quad$ Online Published: March 3, 2016

doi:10.11114/jets.v4i6.1380

URL: http://dx.doi.org/10.11114/jets.v4i6.1380

\begin{abstract}
This paper investigates the experimental studies which test the effectiveness of the concept mapping instructional strategy compared to the traditional teaching method. Meta-analysis was used to calculate the effect size of the concept mapping strategy on academic success. Therefore, the analysis includes experimental studies conducted in Turkey between 2000 and 2015 which compare the concept mapping instructional strategy and the traditional method. 216 master's and doctoral theses and 114 articles were found on the topic. Among these, 73 studies were selected which met the inclusion criteria. These were then combined through meta-analysis. At the end of the study, the concept mapping instructional strategy has been determined to have a significantly positive effect on the Turkish students' academic success $(E S=1,119 ; \mathrm{p}<0,05)$. Considering the population of Turkey, the findings indicate that the effect of concept mapping instructional strategy in terms of academic success was higher than traditional method.
\end{abstract}

Keywords: concept mapping, meta-analysis, academic success

\section{Introduction}

The main idea of concept mapping is based on Ausubel's meaningful learning theory. Starting by discussing the effect of prior knowledge on learning and long-term retention, Ausubel $(1960,1963)$ focused on the cognitive development process and highlighted the importance of developing new ideas with the help of prior knowledge and relationships in mind. According to the meaningful learning theory, students accommodate new concepts and ideas with existing those already ones in their cognitive structure (Novak, 2010).

Instructional strategies that emphasize relating new knowledge to the learner's prior knowledge foster meaningful learning (Novak \& Cañas, 2008). Building on Ausubel's idea of meaningful learning; Novak and Gowin (1984) established an instruction theory, which is based on the Ausubel's meaningful learning idea that integrates concept maps to produce meaningful connections between the concepts in the learner's cognitive structure. A concept map is used as a graphical tool to create and show illustration the connections between ideas and concepts. It is comprised of two elements; namely, the concepts -which are generally embedded in closed shapes such as boxes and circles- and their connections, which are displayed as lines that connect the shapes together (Novak, 1991). Showing all the related concepts and their connections in a diagram or a graph may provide a more comprehensible output than describing them by writing in text. Through this process, one can identify the related concepts in the study and show the hierarchical relationships between them in general (Doğusoy, 2012).

We can see the schematic outline of how learners organize and connect concepts in their mind by the means of concept maps. Concept maps also enable us to cultivate a comprehensive understanding by ensuring that each part of the big idea, their relationships with one another and the whole picture in general is presented through a graphical interface as opposed to ordinal words in a structured text that lacks similar affordances (Lawson, 1994). Visual representations -such as logos, signs and icons- can be recognized easily, interpreted quickly and remembered smoothly (Erdoğan, 2009). Concept maps make use of these phenomena to delineate the connections between the new and old concepts of the learners and force them to objectify those connections (Novak, 1991).

Research studies on concept mapping indicate that it can be used as a useful and effective strategy for both teaching and learning for all grades (Novak, 2010). For instructional purposes, concept mapping fulfills many important roles; by granting pupils a way to reflect their knowledge about a certain subject, by acting as a tool to ease the burden of studying with the means of providing comprehensive understanding on a given subject, by supporting the creation of new ideas and the way these are organized and by facilitating the learning of new concepts and their intricate 
relationships (Doğusoy, 2012; Kavak, 2009; Kanpolat, 2009). Last but not least, concept maps can be used as an assessment tool of pupils' knowledge in a course topic or as an instructional material for teachers to help them (Erdoğan, 2009; Orhan, 2012).

In recent years, many researchers reported in their studies that concept mapping is a successful tool for both teachers and students to teach and learn (Doğusoy, 2012). They have shown that concept maps have positive effects on academic learning outcomes such as success, recall, problem solving, concept learning, repairing previous erroneous conceptualizations and developing critical thinking skills as well as non-academic outcomes such as attitude, perception of self and anxiety (Bıyıkl1, 2015; Baş, 2012, Jonassen, 2011; Kapucu, 2008). Okursoy (2009) revealed that concept maps showed a positive effect on academic succes after a meta-analysis including 33 studies. According to Orhan's study in 2012 and Kavak's study in 2009 concept mapping promoted positive attitudes towards science and self-concepts. Concept maps were also found to increase responsibility for learning (Gurley, 1982), teach mathematics (Burak, 2010; Ozdemir, 2009), chemistry (Aksoy, 2010; Ekmekçioğlu, 2007), physics (Kanpolat, 2009), biology (Bektüzün, 2013; Kasapoglu, 2011; Akay, 2010) and language (Girgin, 2012; Baş, 2012).

To date, numerous studies have been conducted in Turkey about concept mapping instructional strategy in terms of academic succes and retention. This creates a necessity for an analysis of previous researches with a comprehensive and systematic approach. In this respect, a meta-analytic effect analysis of researches should be performed to determine the effect of concept mapping instructional strategy. This study aims to calculate the effectiveness of concept mapping instructional strategy on Turkish students' academic success. In order to find out the effect of concept mapping instructional strategy, 73 experimental studies were attained and used in the meta-analysis. The following research question was stated in the study: "Does concept mapping instructional strategy affect the academic success of Turkish students compared to the traditional teaching method?"

\section{Method}

\subsection{Research Model}

In this study, meta-analysis was used to measure the effect size of concept mapping on Turkish students' academic success. Meta-analysis can be defined as an analysis of previous analyses and is a statistical method used to combine the results of similar studies (Glass, McGaw, \& Smith, 1981). The students of experimental group received instruction by using concept mapping instructional strategy. For the control group, the students received instruction by using traditional teaching methods. They were provided training in the usual way, and no concept mapping strategies were used.

\subsection{Data Collection}

The population of this study consists of articles, proceedings, master's and doctoral theses which were published in the context of concept mapping in Turkey between 2000 and 2015. The theses databases of The Council of Higher Education National Thesis Centre, Google Scholar, ERIC, EBSCO, ProQuest and Ulakbim served as reference. The search using keywords such as 'concept map' and 'concept mapping' in Turkish and English revealed a total of 216 thesis and 114 articles.

The studies which did not fit the inclusion criteria were excluded from the data to be used for meta-analysis. Because of this reason 257 non-experimental studies were excluded from the research data. Finally, 73 experimental studies were found to be related to the topic and compatible with the criteria laid out in our study.

\subsection{Inclusion Criteria}

The criteria for the material to be included in this meta-analytic study are as follows: (i) Time interval: The studies of the last fifteen years only taking place in Turkey; (ii) Students: Level of primary, secondary and higher education; (iii) Sources: All published and unpublished theses, all articles published in academic journals, and proceedings of conferences and symposia; (iv) Research Design: Experimental studies that have control groups and experimental group that will help measure the standardized effect size in meta-analytic studies; (v) Instructional Method: Studies that contain concept mapping as the instructional method; (vi) Sufficient Quantitative Data: Studies that give the values for the control and experimental groups sample size $(\mathrm{N})$, mean $(\mathrm{M})$, standard deviation $(\mathrm{SD})$.

\subsection{Coding Method}

A coding method used to identify all the characteristics of the studies involved in the meta-analysis to make comparisons. The coding method for the current study was composed of two main sections and a total of 9 questions. The first section was called 'study identity' and includes 6 information: the number of study, the name of study, the year, author names, the place of study and publisher names. The second section was called 'study data'. Descriptive statistical data such as sample size, mean values and standard deviation values of the experimental and control groups were 
specified in this section.

\subsection{Data Analysis}

Various statistical accumulation methods have been developed based on the type of results and the choice of statistical model in order to combine the results of studies that investigate the same topic, at different times, in different places and by different people (Higgins, Thompson, Deeks, \& Altman, 2003). In this study, the study effect meta-analysis was employed. This method is used when none of the studies included in the meta-analysis is gathered from different scales (Özcan, 2008). The aim of this method is to calculate the difference between the mean values of the control and experimental groups in experimental studies represented by the formula $\mathrm{d}=(\mathrm{Xe}-\mathrm{Xc}) / \mathrm{SD}$ (Hunter and Schmidt, 1990). The "d" value obtained represents the effect size and forms the basis for meta-analysis.

The inferences rely on two statistical models: the fix effects model and the random effects model. While choosing the model in the meta-analysis, it is possible to test the homogeneity of the size effect distribution (Çömek, Sarıçayır, \& Erdoğan, 2015). In this research, in cases of homogeneity the fix effects model is used, and in other cases the random effects model is used. While calculating the effect sizes (ES) which rely on arithmetic averages, level classification is used for more detailed classification (Thalheimer \& Cook, 2002). (i) Small effect: 0,15 $\leq \mathrm{ES}<0,40$; (ii) Medium effect: $0,40 \leq \mathrm{ES}<0,75$; (iii) Large effect: $0,75 \leq \mathrm{ES}<1,10$; (iv) Very large effect: $1,10 \leq \mathrm{ES}<1,45$; (v) Huge effect: 1,45 $\leq \mathrm{ES}$. Comprehensive Meta-Analysis and MetaWin 2.0 statistical programs were used to calculate effect size and variance values.

\section{Results}

In the meta-analytic analysis based on the result of the literature review 46 master's theses, 12 doctoral theses, and 15 articles were able to combine which provide information on the sample size, arithmetical mean values and standard variation values. Considering all of the 73 studies, the total number of students in the experimental group and in the control group is 2590 and 2535 , respectively. The studies that involve the highest amount of data were conducted in the year 2006, in Ankara, at the second stage of the primary school and in science.

Figure 1 shows Hedge's g effect size, standard error, lower and upper limits and confidence interval of each study. According to Figure 1, the study with the biggest effect size belongs to Özata (2003) and the one with the smallest effect size is Tezcan, Karakuzu, \& Ekmekçi (2011).

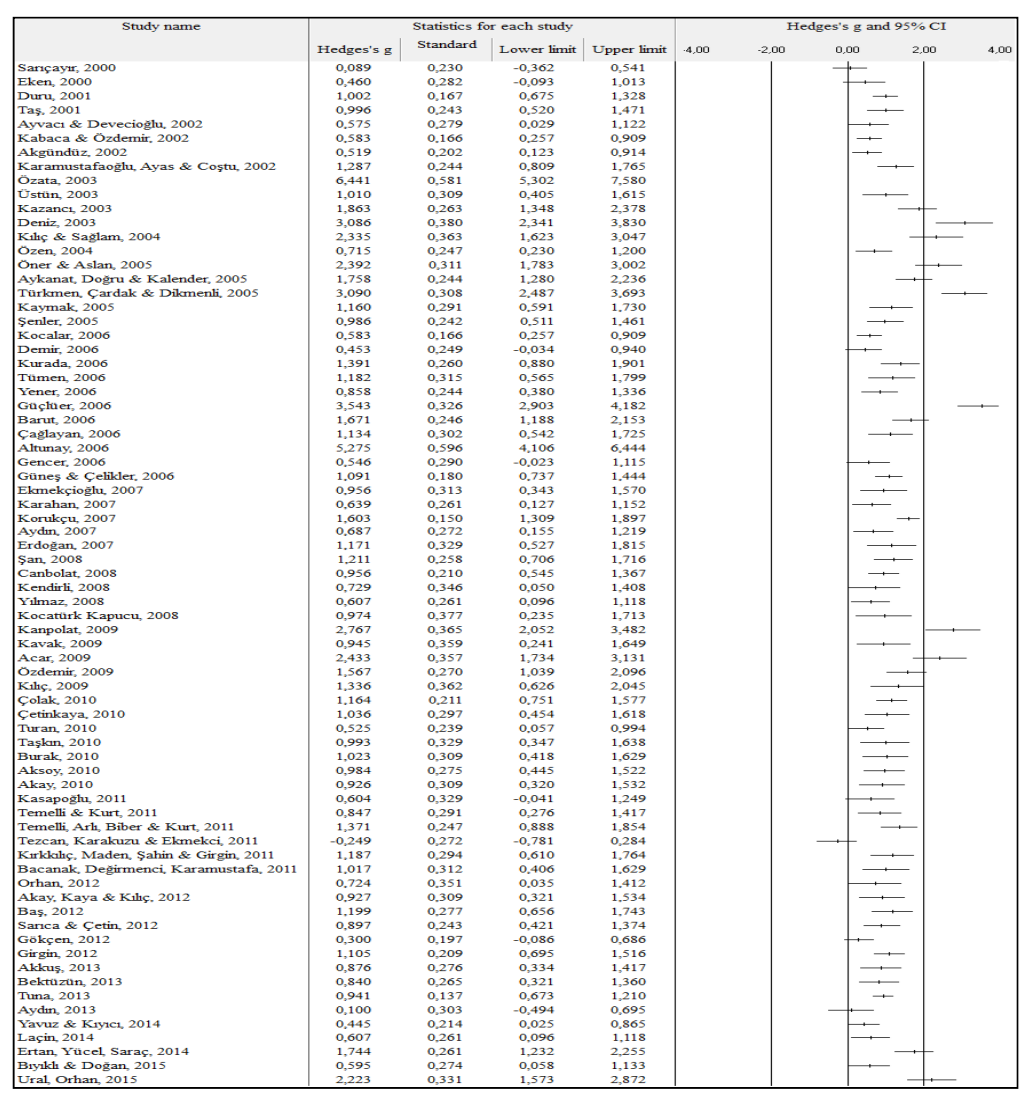

Figure 1. Effect sizes and confidence intervals for each study 
The normal distribution Q-Q graph of the studies included in the research are given in Figure 2 to demonstrate whether it is suitable to combine these studies or not. If the general effect size distribution of the studies combined is within the trust range along the line $\mathrm{X}=\mathrm{Y}$, then it is close to the normal distribution (Rosenberg, Adams, \& Gurevitch, 2000). According to the Figure 2, Özata's (2011) and Altunay's (2006) studies represented by red dots falls outside of the $\pm 1,96$ range. Therefore, these studies were excluded from the meta-analytic process.

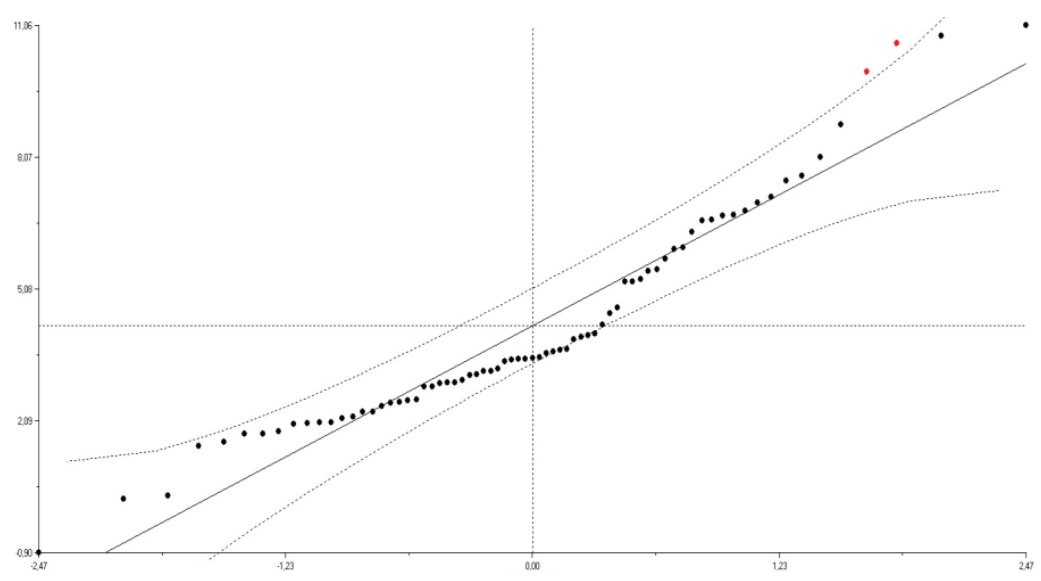

Figure 2. Normal distribution Q-Q graphs of effect size

3.1 Comparison of Traditional Teaching and Concept Mapping Instructional Strategy using Fixed and Random Effects Model

The mean effect sizes, homogeneity distribution values and confidence interval levels of the studies that were incorporated into the meta-analysis are presented in Table 1.

Table 1. Mean Effect Sizes (ES), Homogeneity Values and Confidence Intervals of the Studies According to Effects Models

\begin{tabular}{lcccccc}
\hline \multirow{2}{*}{ Model } & \multirow{2}{*}{$\mathrm{ES}$} & $\mathrm{z}$ & $\mathrm{p}$ & $\mathrm{Q}$ & \multicolumn{2}{c}{$95 \%$ Confidence Interval } \\
& & & & & Lower & Upper \\
\hline Fixed & 1,047 & 34,426 & 0,000 & 405,030 & 0,988 & 1,107 \\
\hline Random & 1,119 & 15,019 & 0,000 & - & 0,973 & 1,265 \\
\hline
\end{tabular}

As shown in Table 1, using the data from the 71 studies included in meta-analysis, fixed effects model was initially applied to data. The results indicate that academic success was higher in concept mapping instructional strategy than in traditional teaching. The mean effect size determined as 1,047 was accepted to be large according to Thalheimer and Cook's (2002) classifications ( $E S=1,047, \mathrm{z}=34,426, \mathrm{p}<0,05)$. On the other hand the chi-square test for homogeneity was conducted to determine whether several populations are similar or equal or homogeneous in some characteristics. Q statistical value was calculated to be 405,030 indicated that the effect size distribution of the studies appears to be heterogeneous according to the fixed effects model $(\mathrm{Q}=405,030 ; \mathrm{p}<0,05)$. Therefore, the random-effects model to synthesize the findings was employed (Raudenbush, 1994).

Mean effect size values in terms of random effects model are presented in Table 1. The results indicate that concept mapping instructional strategy has a positive effect on the Turkish students' academic success $(\mathrm{ES}=1,119, \mathrm{z}=15,019$, $\mathrm{p}<0,05)$. According to Thalheimer \& Cook's (2002) classification system, the effect size found following analysis can be considered as very large.

\section{Discussion}

One of the most important outcomes of the teaching process is academic success. Thus, in order to ensure efficiency of the teaching process and in particular to increase academic success, various teaching methods and techniques are being tested. This paper combined the results of experimental studies about the effects of concept mapping instructional strategy on academic success using meta-analysis methods. For this purpose, the effect size value and direction of concept mapping instructional strategy in terms of academic success were identified. In order to specify the effect of concept mapping instructional strategy on learners' academic success, quantitative studies which compared concept mapping instructional strategy and traditional teaching method published between 2000 and 2015 were investigated. 216 postgraduate thesis (at master's and doctoral level) and 114 articles and presentations on the topic were identified. Out of these studies only the ones which have an experimental research design with a control group were included in meta-analysis. After this first elimination, 73 studies that met the inclusion criteria were then combined using meta-analysis. According to the normality testing two studies falls outside of the $\pm 1,96$ range. Therefore, these studies 
were excluded from the meta-analytic process.

The results of analysis on the data obtained from the 71 studies that were combined in meta-analysis indicated an effect size of ES=1,047, calculated by fixed effects model, in favor of concept mapping instructional strategy. However, the homogeneity test revealed that the studies were heterogeneous and that the data could not be generalized to the whole population. Therefore, in lieu of fixed effects model, the results were recalculated using random effects model. According to the meta-analysis results conducted for the data from 71 studies using random effects model shows that concept mapping instructional strategy has a positive effect on the students' academic success (ES=1,119, $\mathrm{z}=15,019$, $\mathrm{p}<0,05$ ). This value indicated a very large and significant effect size according to the classifications of Thalheimer and Cook, 2002.

The results of the meta-analysis suggested that concept mapping instructional strategy led to greater academic success than traditional teaching method. As the concept maps can be used for many purposes in education, related studies were also conducted to benefit from its effectiveness in Turkey. Many studies are conducted in Turkey related with concept mapping and its effectiveness (Çömek et al.,2016; Laçin, 2014; Bektüzün, 2013; Tuna, 2013; Gökçen, 2012; Girgin, 2012; Şan, 2008). Çömek et al. (2016) investigated the grasping of sixth grade students on the subject of light and sound through concept mapping. The results revealed that concept mapping produced a better acquisition of science understanding than the traditional method. As all mentioned research results and also this research revealed that concept mapping has a positive effect on academic success. This finding is consistent with the results of other national and international meta-analysis studies (Yeşilyurt, 2012; Okursoy, 2009; Horton et al., 1993).

Researchers reported that concept maps can be used in discussing the meaning of the concepts with students (Aydin, 2013); finding and removing misconceptions (Akkuş, 2013); improving high-order thinking skills (Baş, 2013); and assessing what is learned (Orhan, 2012). Structuring of concept mapping is beneficial as a metacognitive tool that enhances the understanding and promotes chances to establish relations with existing structure and new knowledge in science education (Doğusoy, 2012).

On the other hand, meta-analysis research is a kind of research that relies on previous literature. Therefore, it is crucial to access previous studies and the details of those studies in order to reach robust conclusions. One of the obstacle for academic researches in Turkey is the lack of electronic databases to access previous literature. The attempts of the Turkish Council of Higher Education to electronically organize postgraduate thesis at master's and doctoral levels and to make them accessible to researchers could be considered as an important step. Both for meta-analysis and other research, the creation of electronic databases that allows searching various sources such as thesis, articles and presentations could lead to more productive and efficient research in the country (Okursoy, 2009).

The current meta-analysis investigated the effect of concept mapping instructional strategy on academic success. Effects on other issues were excluded from scope of the study. Further meta-analytic research would be appropriate on the effects of concept mapping instructional strategy on factors such as attitude, retention or anxiety. In addition, the effect of computer based concept mappings on academic success could be examined through further meta-analytic studies.

\section{References}

Acar, S. (2009). 10.sinıf coğrafya dersinde toprak konularının kavram haritası tekniği ile işlenmesinin öğrenci başarısına etkisi. Master's Thesis, Gazi University, Ankara.

Akay, S. Ö. (2010). Lise 3. sinıf biyoloji dersinde okutulan boşaltım sistemi konusunun kavram haritaları ile ögretilmesinin ögrencilerin akademik başarısına ve tutumlarına etkisi. Master’s Thesis, Selçuk University, Konya.

Akay, S. Ö., Kaya, B., \& Kılıç, S. (2012). The effects of concept maps on the academic success and attitudes of 11th graders while teaching urinary system. International Online Journal of Primary Education, 1(1), 23-30.

Akgündüz, D. (2002). Illkögretim fen bilgisi ögretimi 6. sınıf biyoloji konularında kavram haritalarının kullanımı ve başarlya olan etkisi. Master's Thesis, Gazi University, Ankara.

Akkuş, G. (2013). 6.sınıf öğrencilerinde dolaşım sistemi konusunda görülen kavram yanılgılarının giderilmesinde bilgisayar destekli kavram haritalarınin etkisi. Master's Thesis, Pamukkale University, Denizli.

Aksoy, M. (2010). Ortaöğretim kimya dersindeki çözünürlük konusunun kavram haritaları ile öğretilmesinin ögrencilerin başarl ve tutumlarına etkisi. Master's Thesis, Selçuk University, Konya.

Altunay, A. Y. (2006). Bilgisayar ortamında hazırlanan kavram haritalarının bir ögretim materyali olarak fen bilgisi dersinde kullanılmasının ilköğretim öğrencilerinin başarllarına etkisi. Master’s Thesis, Selçuk University, Konya.

Ausubel, D. P. (1960). The use of advance organizers in the learning and retention of meaningful verbal material. Journal of Educational Pscyhology, 51(5), 257-272. http://dx.doi.org/10.1037/h0046669 
Ausubel, D. P. (1963). Cognitive structure and the facilitation of meaningful verbal learning. Journal of Teacher Education, 14(2), 217-222. http://dx.doi.org/10.1177/002248716301400220

Aydin, A. (2013). The effects of technology-supported mind and concept mapping on students' construction of science concepts the effect of mind mapping in science education. Anthropologist, 20(2), 166-176.

Aydın, Z. (2007). Isl ve sicaklik konusunda rastlanan kavram yanılglları ve bu kavram yanılgılarının giderilmesinde kavram haritalarınin kullanılması. Master's Thesis, Yüzüncü Yıl University, Van.

Aykanat, F. (2005). Bilgisayar destekli kavram haritalarl yöntemiyle fen ögretimi. Master’s Thesis, Gazi University, Ankara.

Ayvacı, H. Ş., \& Devecioğlu, Y. (2002). Kavram haritasının fen bilgisi başarısına etkisi, Proceedings of the Vth National Science and Mathematics Education Conferences, Middle East Technical University, Ankara.

Bacanak, A., Karamustafaoğlu, S., Değirmenci, S., \& Karamustafaoğlu, O. (2011). Fen öğretiminde bilgi haritası kullanımı: Ekosistem örneği. Ziya Gökalp Eğitim Fakültesi Dergisi, 17(1), 133-145.

Barut, Ö. (2006). İlkögretim 7. slnıf fen bilgisi konularının kavram haritaları ile ögrretilmesi. Master's Thesis, Yüzüncüyıl University, Van.

Baş, G. (2012). The effect of teaching learning strategies in an English lesson on students' achievement, attitudes, and metacognitive awareness. Journal of Theoretical Educational Science, 5(1), 49-71.

Bektüzün, B. (2013). Ortä̈ğretim biyoloji öğretiminde canlıların sinıflandırllması ve biyolojik çeşittilik ünitesinin kavram haritast ile ögretiminin ögrencilerin akademik başarl ve tutumlarına etkisi. Master's Thesis, Gazi University, Ankara.

Bıylklı, C., \& Doğan, N. (2015). The effect of learning strategies used for rehearsal on the academic success. Education and Science, 40(181), 311-327. http://dx.doi.org/10.15390/EB.2015.2728

Burak, B. S. (2010). İlkögretim 6. sinıf matematik dersi geometri öğrenme alanında kavram haritası kullanmanın ögrrencilerin başarıları ve bilgilerinin kalıcllı̆̆ı üzerine etkisi. Master's Thesis, Gazi University, Ankara.

Çağlayan, Ç. (2006). Sekizinci sınıf fen bilgisi dersi genetik ünitesinin öğretiminde kavram haritalarının kullanımının ögrencilerin akademik başarılarına ve kavram kazanmalarına etkisi. Master's Thesis, University of Çukurova, Adana.

Canbolat, S. (2008). Fen ve teknoloji dersinde kavram haritası kullanmanın öğrencilerin başarıları ve tutumlarına etkisi. Master's Thesis, Gazi University, Ankara.

Çetinkaya, M. (2010). Canlıların sinıflandırılması konusu için web destekli kavram haritaları ve anlam çözümleme tablolarının ögrenme üzerindeki etkisinin araştırlması. Master’s Thesis, Ondokuz Mayıs University, İzmir.

Cohen, J. (2013). Statistical power analysis for the behavioral sciences. New Jersey: Lawrence Erlbaum Associates.

Çolak, R. (2010). Kavram haritalarının sosyal bilgiler eğitimi çerçevesinde tarihsel kavramların ögretiminde kullanılması: Kavram haritası ile yapılan öğretimin tutum, başarı ve kalıcılık arasındaki iliş̧kinin incelenmesi. Master's Thesis, Marmara University, İstanbul.

Çömek, A., Akınoğlu, O., Elmacı, E., \& Gündoğdu, T. (2016). The effect of concept mapping on students' academic achievement and attitude in science education. International Journal of Human Sciences, 13(1), 349-363. http://dx.doi.org/10.14687/ijhs.v13i1.3558

Çömek, A., Sarıçayır, H., \& Erdoğan, Y. (2015). Effectiveness of the argumentation method: A meta-analysis. International Journal of Human Sciences, 12(2), 1881-1898. http://dx.doi.org/10.14687/ijhs.v12i2.3522

Demir, E. (2006). 4. ve 5. sinfflar beden eğitimi dersinde basketbol ve badminton ünitelerinde kavram haritalartyla öğretim yönteminin ögrenmeye etkisi. Master's Thesis, Marmara University, İstanbul.

Deniz, F. Ö. (2003). Lise 1 coğrafya derslerinde kavram haritalarının başarıya etkisi. Master’s Thesis, Gazi University, Ankara.

Doğusoy, B. (2012). Cognitive analysis of experts' and novices' concept mapping processes. Doctoral Dissertation, Middle East Technical University, Ankara.

Duru, K. (2001). Illköğretim fen bilgisi dersinde kavram haritasıyla ve gruplara kavram haritası çizdirilerek öğretimin ögrenci başarısina ve hatırlamaya etkisi. Master's Thesis, Marmara University, İstanbul.

Eken, N. (2000). Effect of concept mapping instruction on understanding solution. Master's Thesis, Middle East Technical University, Ankara. 
Ekmekçioğlu, E. (2007). Ortaöğretim Kimya dersinde asit baz konusunun anlamlı öğrenme kuramı ve kavram haritası ile öğretiminin başarlya etkisi. Master's Thesis, Selçuk University, Konya.

Erdoğan, A. (2007). Kavram haritalarının calculus ögretiminde kullanılması. Doctoral Dissertation, Selçuk University, Konya.

Erdoğan, Y. (2009). Paper-based and computer-based concept mappings: The effects on computer achievement, computer anxiety and computer attitude. British Journal of Educational Technology, 40(5), 821-836. http://dx.doi.org/10.1111/j.1467-8535.2008.00856.x

Ertan, Y., Yücel, E., \& Saraç, S. (2014). Kavram haritaları tekniğinin muhasebe eğitiminde kullanılması. Business and Economics Research Journal, 5(1), 107-122.

Gencer, P. B. (2006). İlköğretim altıncı sınıf sosyal bilgiler dersi coğrafya konularında kavram haritalarının öğrenci başarısına etkisi. Master's Thesis, University of Atatürk, Erzurum.

Girgin, Y. (2012). İlköğretim 8. sınıf Türkçe ders kitaplarındaki metinlerde kavram haritası kullanımının öğrencilerin okuduğunu anlama becerileri üzerine etkisi. Master's Thesis, Gazi University, Ankara.

Glass, G., McGaw, B., \& Smith, M. (1981). Meta analysis in social science research. Beverly Hills, CA: Sage Publications.

Gökçen, B. B. (2012). Kavram haritalarının genel biyoloji dersine yönelik tutum ve akademik başarı üzerine etkileri. Master's Thesis, Çanakkale Onsekiz Mart University, Çanakkale.

Güçlüer, E. (2006). İlköğretim fen bilgisi eğitiminde kavram haritalart ile verilen bilişsel desteğin başarıya hatırda tutmaya ve fen bilgisi dersine ilişkin tutuma etkisi. Master's Thesis, University of Dokuz Eylül, İzmir.

Güneş, T., Güneş, M. H., \& Çelikler, D. (2006). Fen bilgisi öğretmenliği biyoloji II ders konularının ögretilmesinde kavram haritası kullanımının öğrenci başarısı üzerine etkileri. Kırşehir Eğitim Fakültesi Dergisi, 7(2), 39-49.

Gurley, L. I. (1982). Use of Gowin's vee and concept mapping strategies to teach responsibility for learning in high school biological sciences. Doctoral Dissertation, University of Cornell.

Hedges, L. V. (1982). Estimation of effect size from a series of independent experiments. Psychological Bulletin, 92(2), 490-499. http://dx.doi.org/10.1037/0033-2909.92.2.490

Higgins, J. P., Thompson, S. G., Deeks, J. J., \& Altman, D. G. (2003). Measuring inconsistency in meta-analyses. BMJ, 327, 557-560. http://dx.doi.org/10.1136/bmj.327.7414.557

Horton, P. B., McConney, A. A., Gallo, M., Woods, A. L., Senn, G. J., \& Hamelin, D. (1993). An investigation of the effectiveness of concept mapping as an instructional tool. Science Education, 77(1), 95-111. http://dx.doi.org/10.1002/sce.3730770107

Hunter, J. E., \& Schmidt, F. L. (1990). Methods of meta-analysis: Correcting error and bias in research findings. London: Sage Publications.

Jonassen, D. (2011). Learning to solve problems.a handbook for designing problem-solving learning environments. New York: Routledge, Taylor and Francis.

Kabaca, T. (2002). Ortä̈ğretim matematik eğitiminde kavram haritalanması tekniğinin kullanımı. Master’s Thesis, Marmara University, İstanbul.

Kanpolat, T. (2009). Lise 2. sinıf öğrencilerinde küresel atmosferik değissimlerin kavram haritaları ile öğretilmesinin ögrencilerin başart ve tutumlarına etkisi. Doctoral Dissertation, Gazi University, Ankara.

Kapucu, N. K. (2008). Bilgisayar destekli kavram haritası kullanımının, öğrencilerin bilişsel senaryo oluşturma becerileri, erişi, ögrenmelerinin kalıcllı̆̆ ve derse yönelik tutumları üzerindeki etkileri. Master's Thesis, Gazi University, Ankara.

Karahan, U. (2007). Alternatif ölçme ve değerlendirme metotlarından grid, tanılayıcı dallanmış ağaç ve kavram haritalarının biyoloji öğretiminde uygulanması. Master's Thesis, Gazi University, Ankara.

Karamustafaoğlu, S., Ayas, A., \& Coştu, B. (2002). Sınıf öğretmeni adaylarının çözeltiler konusundaki kavram yanılgıları ve bu yanılgıların kavram haritası tekniği ile giderilmesi. Proceedings of the Vth National Science and Mathematics Education Conferences, Middle East Technical University, Ankara.

Kasapoğlu, E. (2011). Lise 12. sinuf biyoloji dersi protein sentezi konusunun kavram haritalarlyla öğretiminin öğrencilerin akademik başarllarına ve tutumlarına etkisi. Master's Thesis, Selçuk University, Konya. 
Kavak, K. (2009). İlkögretim 8. sinıf fen ve teknoloji dersi 'maddenin halleri ve isı' ünitesinde kavram haritası tekniği kullanımının öğrencilerin başarısına, bilgilerin kalıcılığına ve fene karşı tutumlarına etkisi. Doctoral Dissertation, Atatürk University, Erzurum.

Kaymak, H. (2005). Kavram haritast yönteminin ögrencilerin periyodik tablo konusunu anlamalarına etkisi. Master's Thesis, Pamukkale University, Denizli.

Kazanc1, M., Atılboz, N. G., Doğan, B. N., \& Altın, M. (2003). Kavram haritalama yönteminin lise 3. sınıf öğrencilerinin genetik konularını öğrenme başarısı üzerine etkisi. Hacettepe University Journal of Educational Faculty, 25, 135-141.

Kendirli, B. (2008). Fen ve teknoloji dersinde kavram haritası kullanımının öğrenci tutumu, başarısı ve bilgi kalıcllı̆ıına etkisi. Master's Thesis, Gazi University, Ankara.

Kılıç, D., \& Sağlam, N. (2004). Biyoloji eğitiminde kavram haritalarının öğrenme başarısına ve kalıcılığına etkisi. Hacettepe University Journal of Educational Faculty, 85, 155-164.

Kılıç, E. (2009). Fen ve teknoloji konularını ögrenme, bilgi kalıcllı̆̆ ve tutumda kavram haritası tekniği ve cinsiyet etkilerinin araştırlması. Master's Thesis, Gazi University, Ankara.

Kırkkılıç, H. A., Maden, S., Şahin, A., \& Girgin, Y. (2011). Kavram haritalarının okuduğunu anlama ve kalıcılık üzerine etkisi. Pegem Eğitim ve Öğretim Dergisi, 1(4), 11-18.

Kocalar, A. O. (2006). Orta öğretim konularında kavram haritalarının coğrafya öğretiminde kullanımı. Master’s Thesis, Marmara University, İstanbul.

Korukçu, A. (2007). Kavram haritalarının din ögretiminde kullanımı. Doctoral Dissertation, Ankara University, Ankara.

Kurada, K. (2006). Lise II tarih dersinin ögretiminde kavram haritası kullanımının ögrenmeye etkisi. Master’s Thesis, Marmara University, İstanbul.

Laçin, F. (2014). Effect of concept mapping and vee diagram on the achievement and attitude of students in statistics and probability for 8th grade in elementary. Master's Thesis, Zirve University, Gaziantep.

Lawson, M. J. (1994). Concept mapping. In T. Husen \& T. N. Postlethwaite (Eds), The international encyclopedia of education, Oxford: Elsevier Science.

Novak, J. D. (1991). Clarify with concept maps: A tool for students and teachers alike. The Science Teacher, 58, 45-49.

Novak, J. D. (2010). Learning, creating, and using knowledge: Concept maps as facilitative tools in schools and corporations. Journal of e-Learning and Knowledge Society, 6(3), 21-30. http://dx.doi.org/10.4324/9780203862001

Novak, J. D., \& Cañas, A. J. (2008). The theory underlying concept maps and how to construct and use them. Technical Report IHMC Cmap Tools, Florida Institute for Human and Machine Cognition.

Novak, J. D., \& Gowin, D. B. (1984). Learning how to learn. Cambridge: Cambridge University Press.

Okursoy, F. (2009). Kavram haritaları öğretim stratejisinin ögrrenci başarısına etkisi: Bir meta analiz çalışması. Master's Thesis, University of Marmara, İstanbul.

Öner, F., \& Arslan, M. (2005). İlköğretim 6. sınıf fen bilgisi dersi elektrik ünitesinde kavram haritaları ile öğretimin öğrenme üzerine etkisi. Turkish Online Journal of Educational Technology, 4(4), 163-169.

Orhan, A. (2012). Alternatif ölçme ve değerlendirme etkinliklerinin 6. sinlffen ve teknoloji dersi yaşamımızdaki elektrik ünitesindeki öğrenci başarlsına etkisi. Master's Thesis, Ahi Evran University, Kırşehir.

Özata, Ö. F. (2003). Illköğretim I. kademe fen bilgisi dersinde kavram haritalarının kavram yanılgılarını gidermeye ve hattrlamaya etkisi. Master's Thesis, University of Marmara, İstanbul.

Özcan, Ş. (2008). Eğitim yöneticisinin cinsiyet ve hizmetiçi eğitim durumunun göreve etkisi: Bir meta analitik etki analizi. Doctoral Dissertation, University of Marmara, İstanbul.

Özdemir, A. (2009). İlköğretim 6. sınıf matematik dersi 'kesirler' konusunun öğretiminde kavram haritası kullanımının ögrenci başarısina etkisi. Master's Thesis, Gazi University, Ankara.

Özen, R. (2004). İlköğretim okullarındaki resim-iş derslerinde kavram haritalarının etkililiği. Master’s Thesis, University of Anadolu, Eskişehir.

Rosenberg, M. S., Adam, D. C., \& Gurevitch, J. (2000). MetaWin: Statistical software for meta-analysis. Sinauer Associates, Sunderland, Massachusetts. 
Şan, İ. (2008). Lise ikinci 2. sınıf biyoloji dersinde okutulan bitkilerde taşıma sistemi konusunun kavram haritalarıyla ögretilmesinin başarlya etkisi. Master's Thesis, Selçuk University, Konya.

Sarıca, R., \& Çetin, B. (2012). Öğretimde kavram haritaları kullanımının öğrencilerin akademik başarısına ve kalıcılığa etkisi. İlkögretim Online, 11(2), 306-318.

Sarıçayır, H. (2000). Lise II kimya derslerinde kavram haritalarının başarıya etkisi. Master's Thesis, University of Marmara, İstanbul.

Şenler, B. (2005). İlköğretim fen bilgisi dersinde dolaşım sistemi konusunun kavram haritalarıyla öğretiminin öğrenci başarısına etkisinin belirlenmesi. Master's Thesis, Muğla University, Muğla.

Taş, B. (2001). Fen bilimleri öğretiminde kavram haritaları üzerine deneysel bir çalışma. Master's Thesis, Celal Bayar University, Manisa.

Taşkın, M. (2010). Sportif tekniğin öğretiminde kavram haritalarının etkisi. Master’s Thesis, Selçuk University, Konya.

Temelli, A., \& Kurt, M. (2011). The effect of using concept maps when teaching the transport system in plants on students' academic achievement. Electronic Journal of Science and Mathematics Education, 5(2), $42-57$.

Temelli, A., Arlı, E. E., Biber, B., \& Kurt, M. (2011). İnsanlarda solunum sistemi konusunun kavram haritalarıyla öğretilmesinin öğrencilerin akademik başarısına etkisi. Iğdır Üniversitesi Fen Bilimleri Enstitüsü Dergisi, 1(2), 61-66.

Tezcan, H., Karakuzu, Z., \& Ekmekci, G. (2011). Madde ve özellikleri konusunun kavratılmasında kavram haritaları destekli öğretimin öğrenci başarısına etkisi. Gazi Eğitim Fakültesi Dergisi, 31(1), 321-338. http://dx.doi.org/10.17152/gefd.28190

Thalheimer, W., \& Cook, S. (2002). How to calculate effect sizes from published research: A simplified methodology. Work-Learning Research, 1-9.

Tümen, S. (2006). Kavram haritaları yönteminin yabancı dil öğretiminde öğrenci başarısına etkisi. Master’s Thesis, Firat University, Elazı̆̆.

Tuna, F. (2013). Coğrafya öğretiminde kavram haritalarının öğrencilerin başarısına etkisi ve öğrencilerin yöntem hakkındaki görüşleri. Mehmet Akif Ersoy Üniversitesi Eğitim Fakültesi Dergisi,13(25), 182-197.

Turan, N. (2010). Alternatif değerlendirme tekniklerinden kavram haritası ve dallanmış ağaç ile klasik değerlendirme tekniklerinin öğrenci başarışı açısından karşılaş̧tırılması. Master’s Thesis, Gazi University, Ankara.

Türkmen, L., Çardak, O., \& Mustafa, D. (2005). Lise 1 biyoloji dersi alan öğrencilerin canlıların çeşitliliği ve sınıflandırılmasıyla ilgili kavram yanılgılarının belirlenmesi ve kavram haritası yardımıyla değiştirilmesi. Journal of Gazi Education Faculty. 25(1), 155-168. http://dx.doi.org/10.17152/gefd.16751

Ural, E., \& Orhan, E. (2015). The effects of web-based educational software enriched by concept maps on learning of structure and properties of matter. Journal of Baltic Science Education, 14(1), 7-19.

Yavuz, M., \& Kıyıcı, F. B. (2014). Laboratuvarda V-diyagramı ve kavram haritası kullanımının başarı ve eleştirel düşünme eğilimine etkisi. Amasya University Ĕ̌itim Fakültesi Dergisi, 3(1), 150-174.

Yener, N. (2006). İlköğretim 7. sinıf fen bilgisi dersinde 'Çevremizde hangi ekosistemler var ve buralarda neler oluyor?' konusunun kavram haritaları ile işlenmesinin öğrenci başarısı ve tutumu üzerinde etkisi. Master’s Thesis, Gazi University, Ankara.

Yeşilyurt, M. (2012). The meta-analysis of the studies measuring the effect of the concept map technique on the success. Energy Education Science and Technology Part B: Social and Educational Studies, 4(1), 31-42.

Yılmaz, H. (2008). Illkögretim birinci kademe 5. sinıf sosyal bilgiler dersinde kavram haritalarının kullanılmasının başartya olan etkisi. Master's Thesis, Selçuk University, Konya.

\section{(cc) $\mathbf{B Y}$}

This work is licensed under a Creative Commons Attribution 3.0 License. 